\title{
Ode to Soil ${ }^{1}$
}

\author{
Graeme D. Buchan
}

"The first Adam, made of earth, came from the earth". I Corinthians 15:47

\begin{abstract}
Water and soil are the 'twin pillars' supporting life on the land. Buchan (1996) reviewed the many 'talents' (wonder properties) of water. This paper reviews: a) the remarkable talents and natural functions of soil - a much more complex (indeed messy!) material; and b) our many uses of soil materials, in agriculture, industry, construction, the environment, and in sport and recreation. Soil is the sustainer of life - our provider and protector. It is the origin of our body minerals (including bones). It is a remarkable store-and-release mechanism for water and nutrients. It is Nature's 'recycling yard': its teeming life forms close the cycle of life by converting dead plant and animal matter into nutrients for inheritor generations. Thus it is the 'living mantle' on the landscape, feeding plants, crops and forests. Further, it makes planet Earth life-friendly by moderating climate; it is a rich source of raw materials; and it supports our sports and recreation. Soil is the second most complex system on the planet - after the human body. Nothing matches it for the huge diversity of its components, and for the point-to-point variability in its properties. Sadly, soil degradation is a major global problem. Improving respect for soil and water is critical for sustainable civilisation on planet Earth.
\end{abstract}

\section{A Preamble: The meanings of 'soil'}

'Paradox' is said to be 'truth spelt with seven letters instead of five'. Water is a paradox (Buchan, 1996). So also is soil: no other word attracts such opposites of meaning (Shorter Oxford Dictionary, 1970). At one extreme, the meanings of soil include "filth", "dirty or refuse matter" and "excrement" ! The verb 'to soil' means "to bring disgrace or discredit upon". But at the other extreme it is reverently described as "The place of one's nativity". Indeed, our material nativity lies at the soil-root interface (Fig. 1): here begins the flow of minerals into plants, and then on into animals. The human body contains about $70 \%$ water; and $7 \%$ minerals, derived mainly from soil (Table 1 ).

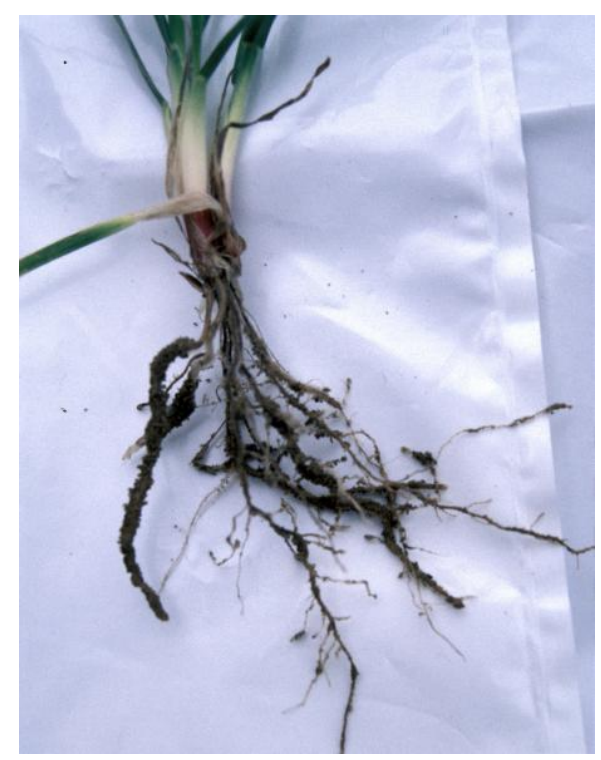

Figure 1. The soil-root interface: where human life begins. Nutrients flow along the soil $\rightarrow$ plant $\rightarrow$ animal supply chain. The root's absorption efficiency is greatly enhanced by rhizosphere microbes (fungi and bacteria). Roots absorb water partly by osmotic attraction, because their cells contain solutes (including ions and proteins).

\footnotetext{
${ }^{1}$ This is the third in a series of 'resource appreciation' papers, designed to encourage a) positive (in contrast to the often-felt negative) feelings about environmental issues, and b) the valuing of Nature's resources. The author's preceding papers were 'Ode to Planet Earth' and 'Ode to $\mathrm{H}_{2} \mathrm{O}$ ' (see References).
} 
In agriculture and ecology, 'soil' means the top 1 to 2 metres of life-bearing material. To engineers it is mainly inert (lifeless) material under structures, and to geologists it includes deep sediments. Here 'soil' is widely interpreted, as 'earth surface materials': it is any particulate material (e.g. topsoil, sand) containing sand, silt or clay particles (Table 2), and with or without organic matter. Soil is the 'fines' (i.e. particles $<2 \mathrm{~mm}$ in size) produced by the break-down and weathering of rock, or volcano emissions. While our most important soil is the plant-nourishing mantle on the land enriched by organic matter, buried soil materials (e.g. sand or clay from quarries) are also vital resources for our technologies.

\begin{tabular}{|c|c|}
\hline & \% \\
\hline $\mathrm{H}_{2} \mathrm{O}$ & $65-70$ \\
\hline Carbon (from air via plants) & 18 \\
\hline Nitrogen and other minerals (from soil) & $\mathbf{7}$ \\
\hline
\end{tabular}

Table 1 Composition of the human body (Data from Walker, 1990)

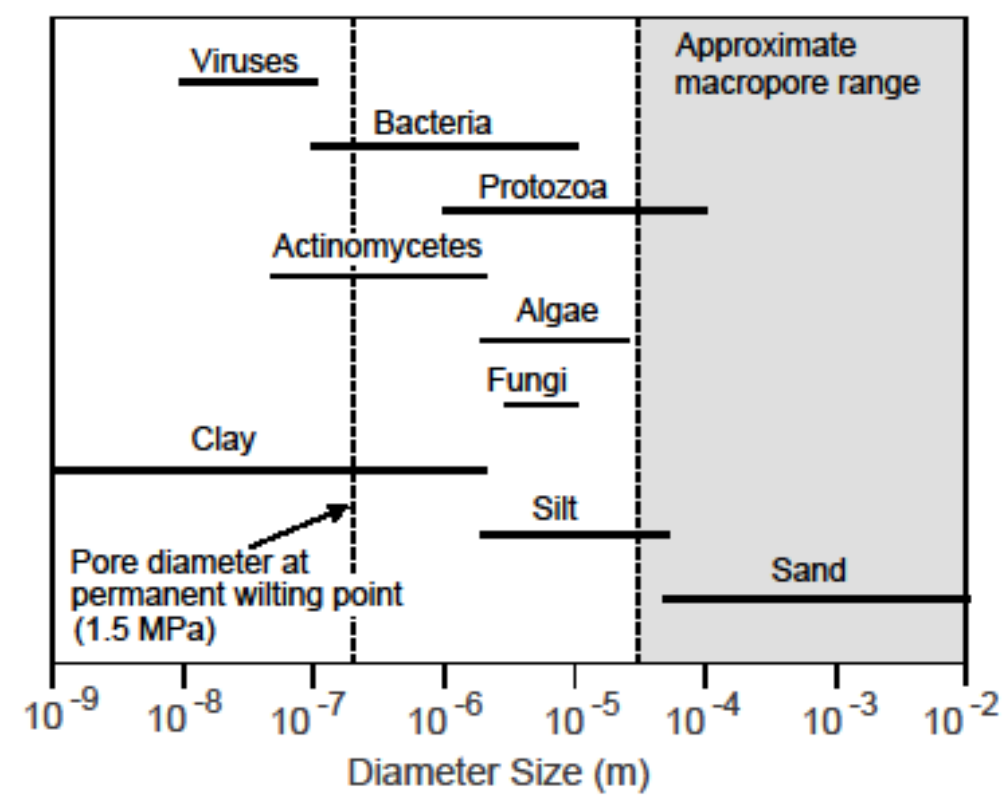

Table 2 The relative sizes of a) soil particles, and b) microbes (bacteria etc.)

\section{Introduction}

This article has two purposes. First it summarises the key properties and natural functions of soil. Second, it reviews our many uses of soil materials, including non-agricultural uses. 


\section{The Nature of Soil}

\section{Soil's main components: Complex stuff !}

Soil is very, very complex. Its solid phase contains three main materials:

1) mineral particles;

2) organic matter - both living biota (roots, and a rich array of microscopic lifeforms), plus a very complex array of organic materials; and

3) ions, either dissolved in water, or stored on mineral and organic particles (Fig. 2).

Soil is not just a skin on the land. It is also sediments found deeper in Mother Earth's 'complexion'. On a geological time-scale, rising and falling sea levels have historically flooded some land surfaces, forming complex layered systems e.g., the Canterbury Plains in New Zealand (Fig.3).

Soil may look highly disordered, but it does have some order or 'structure'. Its components are bonded together by clays, organic matter, and mineral oxides, and also by a living mesh of roots and fungi. These bonds are often easily broken, or weakened by the remarkable softening power of water (Buchan 1996). Thus soil is physically 'alive': it continuously reforms its structure, especially by wetting and drying cycles.

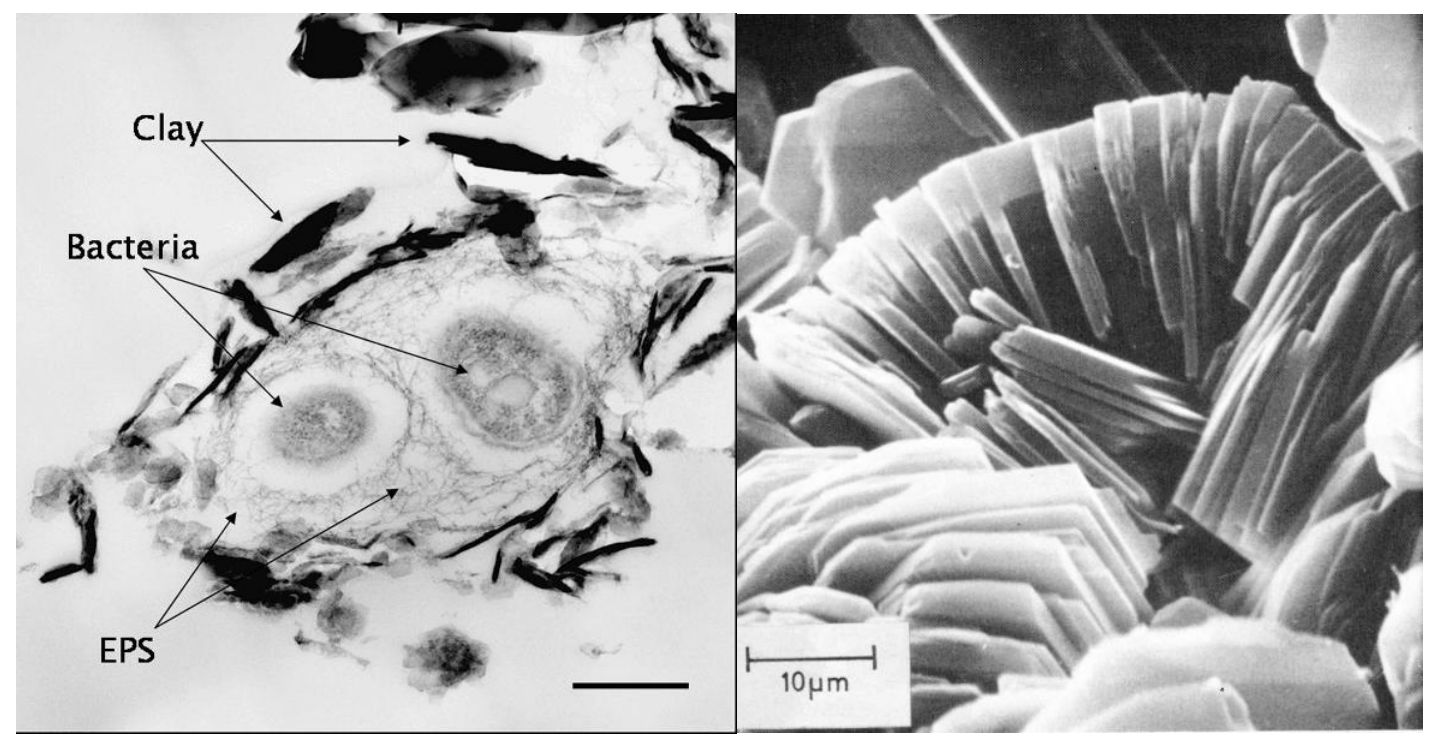

A

B

Figure 2 Clay particles and bacteria (both about $1 \mu \mathrm{m}$ in size), as seen with electron microscopes

A) Bacteria and clay particles. The scale bar is $0.4 \mu \mathrm{m}$ long. The bacteria produce extracellular polymeric substances (EPS), which help the bacteria to stick together, or to soil particles (Environment Canada, 2004).

B) A 'domain' of kaolin clay particles, showing how they are stacked in an ordered arrangement. The spaces between the particles contain water and ions. Water added to soil is attracted into the spaces between particles, causing swelling. 'Firing' the clay in an oven removes the water, bonding the particles into hard porcelain. See also Appendix 2. 


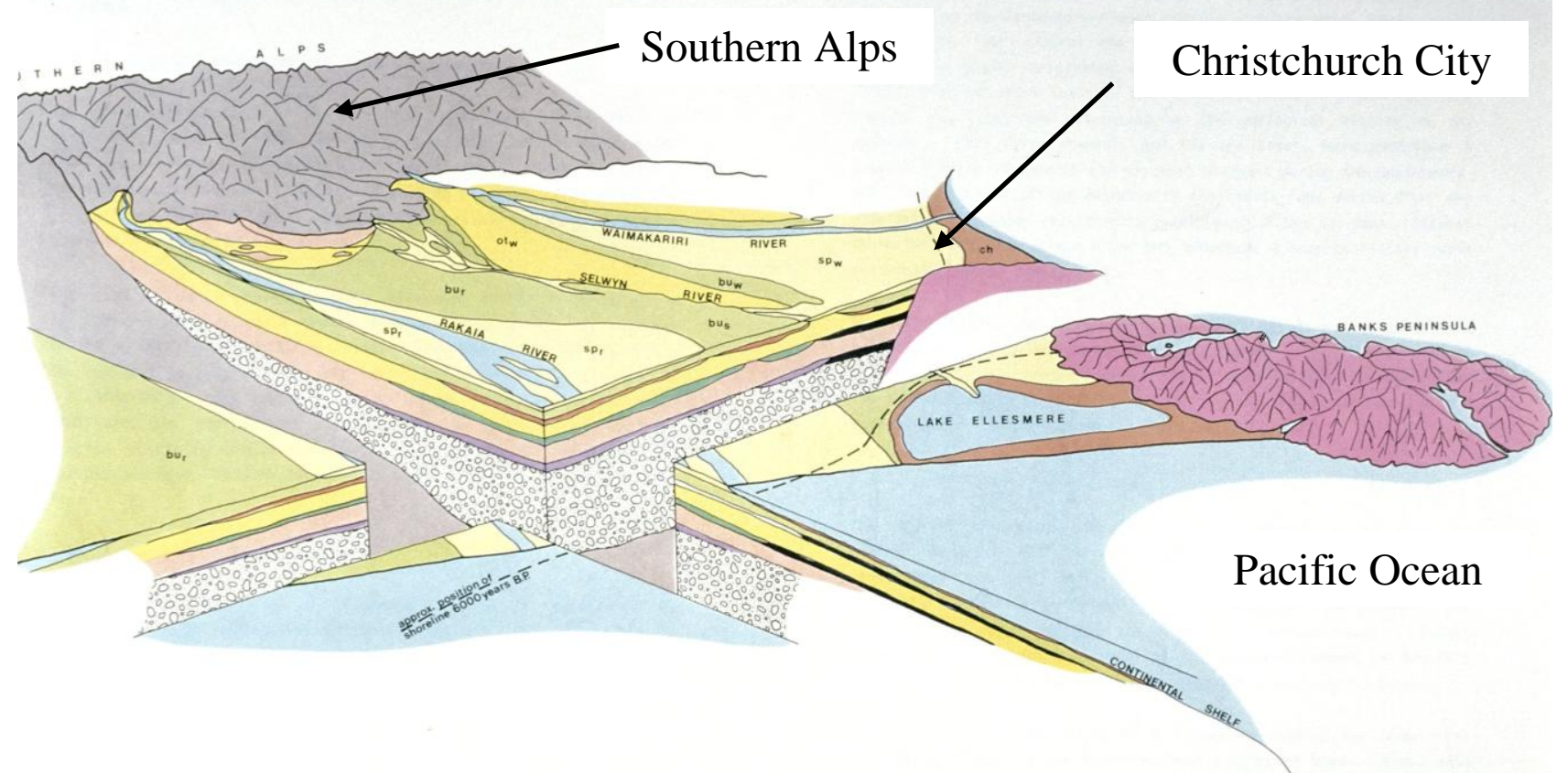

Figure 3 Stratigraphy (i.e. layering) of the Canterbury Plains, in NZ's South Island The soil materials form a 'layer cake' structure, overlying a basement of bedrock at depths up to 500 metres. The layers are either: a) permeable sands and gravels, which form 'aquifers' (water-carrying layers providing very pure groundwater for humans); or b) impermeable marine clay layers, formed when ocean covered the land (From Bowden, 1983). See also Appendix 3.

\section{Soil Minerals}

The mineral particles (Table 2 and Fig. 2) come from rock. Sand and silt particles (the 'primary minerals') are mainly fragments of rocks such as quartz or limestone. Clay particles (the 'secondary minerals') are quite different: they result from complete chemical transformation of the primary minerals, including their slow dissolving and recrystallisation. The largest clay particles are about the same size as a bacterium (about 1 $\mu \mathrm{m}$, Fig. 2). Clay has two remarkable properties (Fig. 2B):

1) It has large surface area. A mere 0.1 gram of clay (about $2 \%$ of the weight of a credit card) has a surface area of about $1 \mathrm{~m}^{2}$ (almost the body surface area of an adult!).

2) Most particles have strong surface charge (mainly negative).

So clay is the main colloid (i.e. 'surface active') soil component. It has strong 'stickability'. It bonds soil particles together, and adsorbs water and nutrients, e.g. calcium $\left(\mathrm{Ca}^{++}\right)$ ions. Pure sand and silt particles have relatively inert (inactive) surfaces. On their own they would give soils weak cohesion, and poor ability to adsorb water or ions. But Nature sometimes coats these particles with metal oxides or organic matter, enabling the particles to bond, and retain nutrients (Adams and Gibbs, 1994).

\section{Organic matter (OM)}

OM exists in various states of decay, from fresh deposits (e.g. leaves, roots) to almost fully decomposed humus. Humus, like clay, is a colloid with strong surface activity. A soil rich in $\mathrm{OM}(>70 \%)$ is a 'peat'. OM also bonds particles and stabilises soil structure. It contributes to the 'inner architecture' of the pore space. In fact it tends to open up soil porosity. It is the 'yeast of the soil', turning it into more 'holesome' stuff! Decay of OM adds complex organic acids to soil, plus $\mathrm{CO}_{2}$ gas, which acidifies and accelerates the weathering of soils. 
Did you know?

A 'hyperactive' soil caused the failure of 'Biosphere 2'.

Biosphere 2 was a transparent, 3 acre enclosure in the Arizona desert, containing a closed, artificial ecosystem (including plants and humans). It was designed to simulate planet Earth (which is 'Biosphere 1').

Why did it fail? Answer: It had excessive soil organic matter. Microbes decomposing this OM lowered oxygen levels in the atmosphere to life-unfriendly levels (Vergano, 1996).

Ions The nutrients which are vital for plants are either positive cations (e.g. $\mathrm{Ca}^{++}, \mathrm{K}^{+}$, $\mathrm{Mg}^{++}$), or negative anions (e.g. nitrate or phosphate). Clay and organic particles, with their mainly negative surfaces, can adsorb large quantities of cations. A soil's cation exchange capacity (CEC) is a measure of its adsorption power, i.e. its ability to store and release nutrients. $\mathrm{Ca}^{++}$is often a dominant cation, at the start of the soil $\rightarrow$ plant $\rightarrow$ animal supply chain, which provides calcium for bones. By contrast, negative anions (e.g. nitrate $\mathrm{NO}_{3}{ }^{-}$) are repelled by soil's negative charges, so are easily leached from soil. Hence nitrate contamination of groundwater is a worldwide problem.

\section{Physical aspects of soil}

Soil minerals have a density of about $2.65 \mathrm{~g} \mathrm{~cm}^{-3}$ (similar to most rocks), about 2.5 times the density of water. This is slightly denser than common silica glass $\left(2.2 \mathrm{~g} \mathrm{~cm}^{-3}\right)$, due to heavier elements (such as aluminium).

Did you know?

- The average density of planet Earth is $5.5 \mathrm{~g} \mathrm{~cm}^{-3}$. Earth's thin continental crusts consist of rock material with density c. $2.65 \mathrm{~g} \mathrm{~cm}^{-3}$ (similar to soil particles). They float on denser materials beneath (Buchan, 1994).

A trick question!

- Which is denser - organic matter (OM, e.g. wood fibre) or water?

Answer: $\mathrm{OM}$ is denser, with a material density about $1.3 \mathrm{~g} \mathrm{~cm}^{-3}$. Think about it: 'waterlogged' wood or saturated tea leaves sink in water!

Water storage Water and soil are powerful partners supporting life on the land. Their strong mutual attraction makes soil a 'reservoir' of water for plants - thanks to the wonder properties of water (Buchan 1986), including its strong polarity and large surface tension. This results in powerful $a b$ sorption of water into soil pores, and $a d$ sorption onto particle surfaces.

\section{Soil air exchange}

Soil is alive with microbes, roots and other life-forms, which (like humans) need to respire, i.e. consume oxygen and release energy, giving out $\mathrm{CO}_{2}$. So soil 'breathes' through its surface layers. A square metre of soil may 'breathe' in about 10 or more litres of oxygen per day (Currie, 1970). For comparison, a sitting adult requires about 500 litres of oxygen per day (Keele et al., 1982).

\section{Soil degradation and erosion}

Soil degradation caused by humans is proceeding at a rapid pace, mainly by erosion (Appendix 1). Erosion is either natural, or accelerated (caused by humans). Natural 
erosion occurs on a grand scale and is vital - it has deposited and formed our soils. But accelerated erosion now causes loss of about 10 million ha of world cropland each year! (Pimentel, 2006)

\section{Did you know?}

Erosion is estimated to remove from the land over 75 billion tons of soil per year (Wilkinson and McElroy, 2007; Pimentel et al., 1995). Much of this soil is redistributed and concentrated at other places on the landscape, or in reservoirs or dams. Only about 16 billion tons per year (i.e. about 20\%) is discharged by rivers to the oceans (Ludwig and Probst, 1998). See Appendices 1 and 3.

Tiny soil particles, windblown high into the atmosphere, provide part of Nature's range of 'cloud condensation nuclei' (CCN). These CCN are essential for seeding the formation of cloud droplets or ice crystals, and hence raindrops or snow. So again, water and soil are partners in the hydrological cycle.

\section{Chemical aspects of soil}

Soils tend to resist rapid chemical changes, i.e. they are 'buffered'. For example, soil acidity changes very slowly, thanks to soil's ability to adsorb ions onto its surfaces (Yong et al. 1992). Soil is like a giant chemical exchange material covering Earth's surface, capturing and releasing ions and nutrients, and buffering ecosystems against rapid changes, e.g. in the acidity of rainwater.

Soil: a water cleanser and conditioner. Soils, buried sediments and rocks also 'condition' the state of waters on planet Earth. Deep groundwater has often percolated through layers of soils and sediments, which filter out impurities and contaminants, and also add dissolved minerals - hence the term 'mineral water' (Snoeyink and Jenkins, 1980).

Soil colour originates from several components. Organic matter darkens soils.

Sesquioxides (i.e. iron and aluminium-based minerals) give soil other colours e.g. haematite (iron-based) is red, and goethite is yellowish-brown. Brown or red colours indicate the presence of iron compounds, showing that the soil has been 'weathered'.

\section{Did you know?}

Eating soil (geophagia) is a custom among some peoples (as well wildlife and curious infants!). It can have several benefits: it supplements trace elements in the diet; or detoxifies foods by adsorbing toxins onto particle surfaces (Oliver 1997). See Fig. 6.

\section{Soil microbes}

\section{Biological aspects of soil}

The soil is densely populated with microbes (including protozoa, bacteria, fungi and viruses). See Figure 2 and Table 2. One tablespoon of agricultural soil has more organisms in it than people on Earth. Soil microbes help close several of Nature's cycles, including the nitrogen and carbon cycles. Soil is the great digester, decomposing and returning to the biosphere huge amounts of plant and animal wastes. 
Did you know?

- Soil is also a reservoir of diseases. These include tetanus (Fig. 4), anthrax and hookworms (Oliver, 1997).

- Most clinical antibiotics, including penicillin, originate from soil microbes (Clewell, 2008).

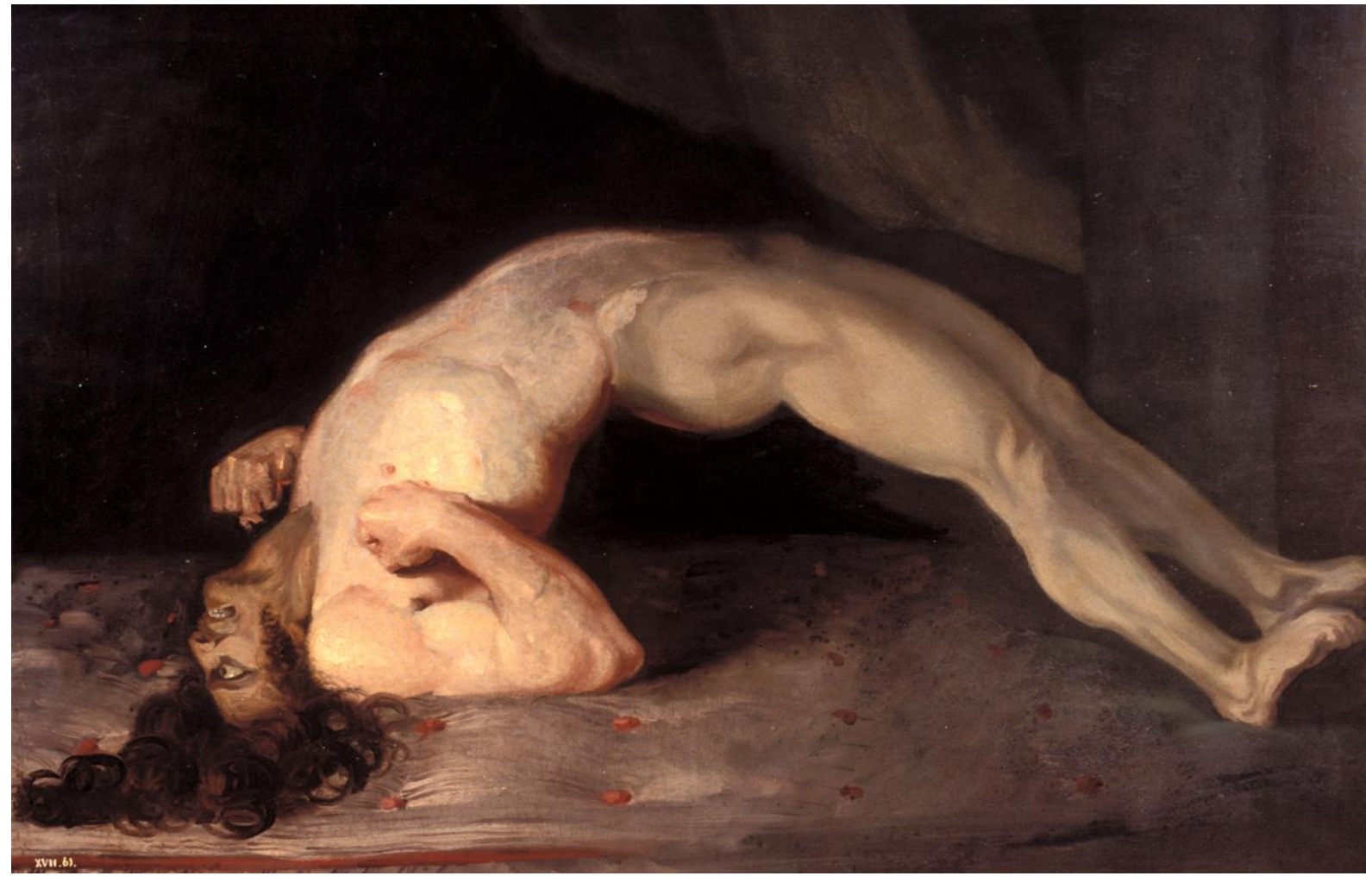

Figure 4. Most soil microbes are beneficial for soil activity, or harmless to humans. But soil also contains pathogens, e.g. for tetanus or legionnaire's disease. This painting shows a soldier dying from tetanus, a bacterial infection harboured in soil.

(Painting by Charles Bell. Reproduced by permission of the President and Fellows of the Royal College of Surgeons of Edinburgh).

\section{Plants}

Plants are the main conveyors of the Sun's energy (and hence life!) to the soil 'reactor'. They provide organic matter, and food for microbes. Roots interact subtly with soil. Nitrogen-fixing bacteria live in symbiosis with roots of some plants, providing natural $\mathrm{N}$ fertiliser. In NZ, 'free' nitrogen from clover (an example of an 'ecosystem service') is worth over one billion dollars per year to agriculture ( $\sim 300$ per person each year). Root-to-soil contact is enhanced by another symbiosis: the rhizosphere is a sheath of microbes (fungi and bacteria) surrounding root fibres, which enhances their uptake of water and nutrients (Fig. 1).

Worms - are Nature's gardeners, and the 'engineers' of the underworld. Darwin recognised their huge role as biological cultivators. In a fertile soil worms can digest as much as 90 tonnes of soil per hectare each year, helping to inter-mix soil layers. (For comparison, a good wheat crop yields 10 tonnes per hectare). Wormholes are Nature's ventilation shafts and drainpipes. They speed up soil's acceptance of surface water, reducing water runoff and erosion. Without worms, soils today would be more eroded, thinner and less fertile. 
Did you know? In a fertile pasture the weight of earthworms below the surface can exceed that of grazing animals above ! (Yeates, 1989).

\section{Natural Roles of Soil}

\section{Soil and water: clean-up partners}

Water entering soil can carry suspended material and contaminants; but it is filtered as it percolates through the soil, which cleanses it before it reaches groundwater. About $1 / 3^{\text {rd }}$ of all housing units in the USA dispose of wastewater via on-site septic tanks, with soil acting as the final receiver and cleanser of the treated wastewater.

While soil cleanses water, water also cleanses soils! As soil minerals slowly break down, they release salts. In dry climates, this results in salt-affected soils, i.e. soils with an excess of salts or sodium. Fortunately, Earth has a huge flushing system. Water evaporating from Earth's $70 \%$ ocean cover delivers excess rain to most of the $30 \%$ land, which leaches out excess salts from soil. This is Nature "doing its washing".

Did you know?

90\% of world soils are clean (free from salt problems). In suitable climates they support productive crops. Only the remaining 10\% are salt-affected (Szabolcs, 1989).

\section{Soil - the climate controller}

Soils emit and absorb several greenhouse gases, including $\mathrm{CO}_{2}$, methane and nitrous oxide. So they also help regulate Earth's climate.

Did you know?

- Earth's land cover (plants and soils) absorb about 29\% of anthropogenic $\mathrm{CO}_{2}$ emissions. This helps reduce global warming (Global Carbon Project, 2009).

- World soils contain about twice the total carbon in the atmosphere (Blum, 2005; Wilding and Lin, 2005).

\section{Heat storage}

Soil is a powerful climate moderator. It prevents surface temperatures swinging to hostile extremes. The biosphere pulses with two rhythms: the daily and annual cycles of temperature. Soil plays two vital roles:

1. Daytime. Soil is the vital water reservoir, supplying water to transpiring plants. Their evaporation helps cool Earth's 'skin'.

2. Night-time. Soil is a heat reservoir. It is Nature's 'storage heater', storing solar heat in daytime, and then releasing it at night. Without this, night-time temperatures would plummet, and freeze and kill all but the most basic life forms. Similarly, the soil moderates summer-to-winter temperature swings. Below about $8 \mathrm{~m}$ depth, temperature remains almost constant all year.

Did you know?

Soil is cool! The residents of Coober Pedy, a mining town in Australia, suffer stifling daytime air temperatures, so have built much of their town underground, where it stays tolerably cool. 


\section{Uses of soil}

This section reviews non-agricultural uses of soil materials. Since most involve use of clays, these are reviewed first.

\section{Uses of clays}

Globally, humans extract more than 135 million tonnes per year of different clays for industrial, construction, agricultural and environmental purposes (Murray, 1993).

\section{Industrial uses}

Clays are used widely as follows.

- Ceramics and porcelains. Firing clay at high temperatures drives out inter-particle moisture. This pulls particles together so that they bond to form strong materials, such as porcelain or pottery. (See Fig. 2B).

- Papermaking. Clays (e.g. kaolin) are used as 'fillers', closing the tiny gaps between cellulose fibres. This enables printing of higher resolution images, increases paper strength, and can also act as a whitening pigment.

- Paint. Kaolin is used alongside titanium dioxide in water-based paints. Small particles give high-gloss paints, while larger particles give a 'flat' finish. Clay also acts as a 'carrier' for the colouring pigments (Velde, 1995).

- The petroleum industry uses over 300,000 tonnes of kaolin per year as a catalyst in the breakdown (or 'cracking') of larger hydrocarbon molecules.

- Montmorillonite clays (called 'bentonite' in industry) are used in oil-well drilling muds.

Clays are also used in a host of everyday products, including cleaning agents, and in the clarification of beer and wine! (Murray 1993).

\section{Construction uses}

Huge quantities of soil are used for building materials (Allen, 1997). See Fig. 5. Bricks are made from kiln-fired clay or silt. Mud can be moulded into bricks to build adobe houses, which have excellent heat insulation. Soil is also used to construct earth dams. During the Red River floods in Canada in 1997, $47 \mathrm{~km}$ of earth dikes were built over a few days, helping save Winnipeg and its surroundings from severe flooding !

Did you know? The bricks in Buckingham Palace, London, were made from loess (i.e. windblown silt) deposits from North Kent, England.

\section{Environmental uses}

Compacted clay (e.g. montmorillonite) makes an excellent sealing or 'lining' layer, e.g. in irrigation ditches, dams and ponds; or as a 'liner' in modern waste landfills, making them 'watertight' against water entry in, and leaching losses out. Clays also have strong exchange capacity, and hence can capture contaminants. So, they can block the migration of toxic or hazardous wastes out of the landfill.

\section{Soils for sports}

Soil properties are critical for sports. For wet-weather surfaces (playing fields or golf greens) the best support is a sand or sandy soil. They are free-draining, and compact to provide a stable, non-sticky, non-pugging, non-slip surface for foot traffic. By contrast, for dry-weather cricket pitches or grassed tennis courts, the best surfaces are dry, compact clays, which provide good 'bounce' for the ball (Adams and Gibbs, 1994). 

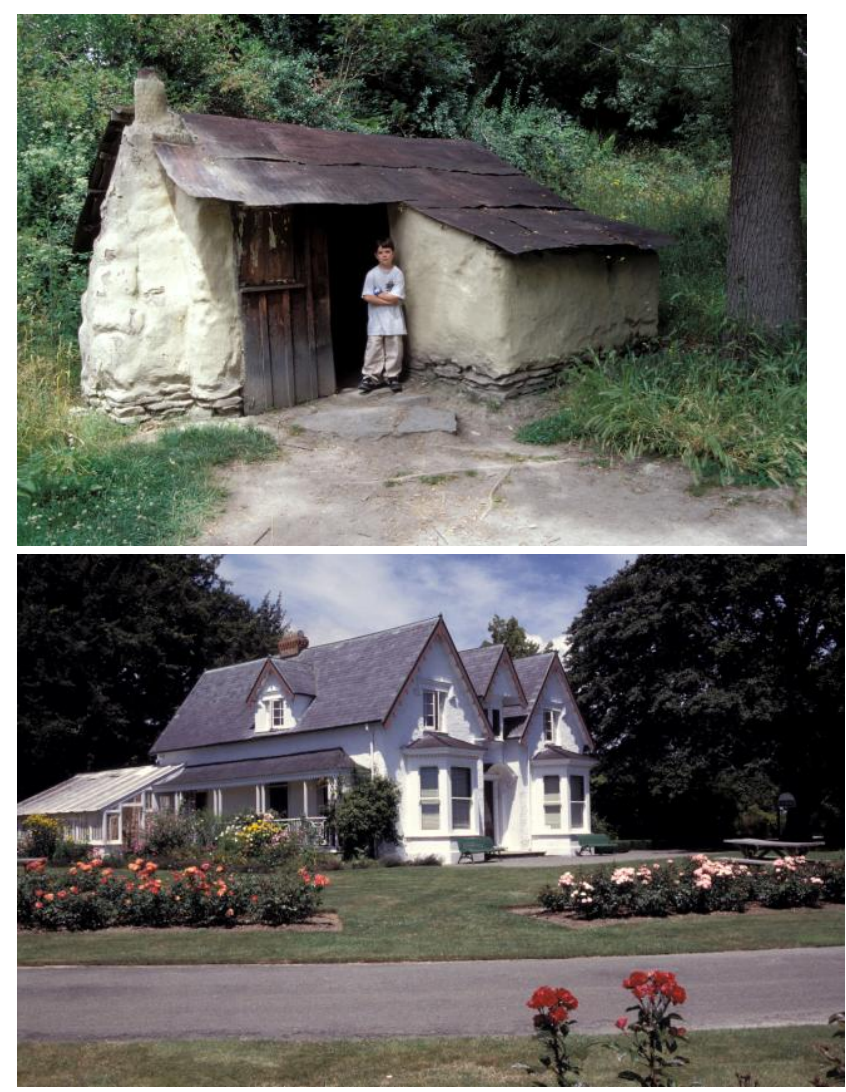

\section{Figure 5 Soil for construction}

Top: A $19^{\text {th }}$ century home in the Chinese Village, Arrowtown, NZ. Bottom: Broadgreen House, Nelson, NZ. The walls of these house are partly constructed from earth material. Earth-building of homes is increasingly recognised as a 'sustainable' construction method.

\section{Conclusions}

Imagine being given this task: "Design a life-enabling planet". One major sub-task: you must 'invent' a material to cover the land and support its life. Specifications include: it must store and release water and gases, and drain away excess water; it must act as a chemical 'factory', generating, storing and releasing nutrients; and as a 'bioreactor', cycling Nature's huge annual yields of dead organic material back into the biosphere; it must help regulate microclimate; it should be strong enough to support plants and animals, and resist erosion, yet weak enough to enable penetration by roots and worms. You would surely design...... soil: that marvellous, 'holesome' material, a myriad of tiny particles and pores. Crops can be grown in 'soil-less' media: in hydroponics (roots dangling in nutrient solution); or even aeroponics! (roots dangling in air, sprayed by nutrient solution). However these high-tech methods suit only small-scale growth of high-value crops. Our major foodstocks will always require large-scale cropping of field soils.

Soil is the 'terra incognita', the hidden half. We spend large resources exploring outer space, while much remains unknown of the 'inner space' of the soil, especially at the soilroot interface. Soil is the very source of civilisation: "Culture begins with cultivation". It is the beginning and end place for land-borne life, a vital link in the cycles of life: the digester of the dead and the birthplace of the new. Life should be a covenant between people and the land. Just as soil gives us life, we should be custodians of the life of the soil. Let us value and conserve soil, 'the place of our nativity'. 


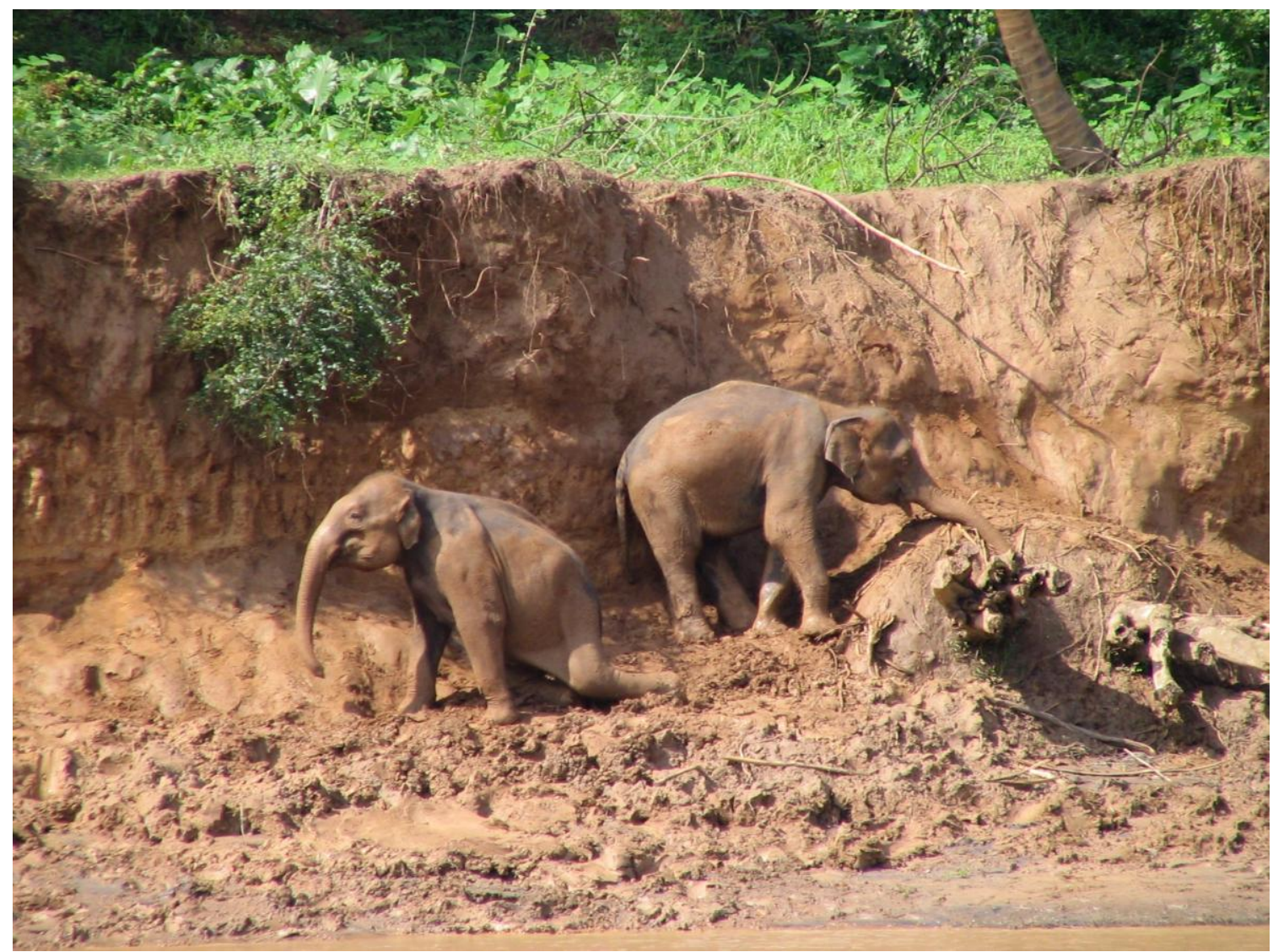

Figure 6 Elephants in an elephant orphanage in Sri Lanka are enjoying riverbank mud bathing! By drinking the 'dirty' river water with its suspended soil particles, they also ingest soil minerals. See also Appendix 3.

\section{APPENDIX 1 : Soil degradation}

The loss of productive soil is among our top few environmental threats. Civilisations have risen and fallen on their soils. A leading factor in the decline of Mesopotamia (now part of Iraq) was the slow salinisation (accumulation of excess salts) in its once productive soils, leading to declining crop yields (Hillel, 1998).

Worldwide, about 12 million hectares per year of arable land are degraded and abandoned by humans - about $0.8 \%$ of all cultivated land (Pimentel et al., 1995). Erosion is the main cause. In the US and Europe, erosion skims off the land about $1.7 \mathrm{~mm}$ of soil per year, while new soil forms naturally at only about $0.1 \mathrm{~mm}$ per year (Pimentel et al., 1995). The 'World Clocks' (http://tranquileye.com/clock/) has two digital displays: the population clock counts quietly upwards; while the second, showing Earth's productive land area, counts downwards. They tell a clear story of unsustainable practices.

\section{APPENDIX 2 : The bonding and separation of soil particles}

Inter-particle forces are critical for the behaviour of a) bulk soils in the field, and b) clay and organic particles suspended in water (e.g. in rivers or oceans). The attraction or repulsion of particles is controlled by the types of particles, the soil's wetness, and the types of cations in solution. If particles are weakly bonded, and then exposed to a very dilute solution (e.g. rainwater), the water invades the inter-particle spaces, causing dispersion. By contrast, if dispersed particles are exposed to a highly concentrated solution such as seawater, the 
reverse attraction of water to the ions (osmosis) can reverse the dispersion, causing flocculation (i.e. the clustering of particles into 'flocs'). See also Fig. 2 B.

Did you know?

River or swimming pool water containing suspended clay or organic particles (e.g. Fig. 6) can be clarified for human use by adding alum (aluminium sulphate) as a 'flocculating agent'. In a similar process, blood clotting involves coagulation of blood platelets, and can be speeded up by aluminium ions. Alum (in the form of a 'styptic pencil') dabbed on skin halts bleeding from minor (e.g. shaving) cuts.

APPENDIX 3: Why are the oceans not muddy ?

Rivers and lakes typically carry fine clay or organic particles in suspension (Fig. 6). Earth's hydrological cycle is a soil 'conveyor belt', sweeping soil material (including silt and clay) into the oceans, at the rate of about 16 billion tons per year (Ludwig and Probst, 1998). Fortunately the oceans remain clear, enabling sunlight to reach phytoplankton, at the start of the ocean food chain. Why are the oceans clear and not muddy? Answer: the high concentration of salts in seawater causes suspended particles to bind into groups ('flocs') and settle out as ocean-bottom sediments. (See Appendix 2). Some old marine clay layers, now under the land, are effectively watertight. They form 'confining layers' which trap and protect huge aquifers (groundwater 'lenses'). These aquifers are conveniently available for use by humans (Fig. 3). So salts in the sea make it self-clarifying.

\section{REFERENCES CITED}

Adams, W.A. and Gibbs, R.J. 1994. Natural Turffor Sport and Amenity: Science and Practice. CAB International, Wallingford, U.K.

Allen, M. 1997. Out of the Ground. Earth building in New Zealand. The Dunmore Press, Palmerston North, NZ.

Bowden, M.J. 1983. Interim Report on the Groundwater Resource of the Central Plains. Resource Investigations Division, North Canterbury Catchment Board, NZ. TC 522.6.C2

Blum, W.H., 2005. Functions of soil for society and the environment. Reviews in Environmental Sci. \& Bio/Tech. 4: 75-79.

Buchan, G.D. 1994. Ode to Planet Earth. Journal of Environmental Education 26(1): 5-8. See http://researcharchive.lincoln.ac.nz/dspace/handle/10182/302

Buchan, G.D. 1996. Ode to $\mathrm{H}_{2} \mathrm{O}$. Journal of Soil and Water Conservation 51(6): 467-470. See http://hdl.handle.net/10182/333

Clewell, D. 2008. Antibiotic Resistance in Bacteria: Origins and Emergence. SciTopics. www.scitopics.com/Antibiotic_Resistance_in_Bacteria_Origins_and_Emergence.html Verified Nov 2009.

Currie, J.A., 1970. Movement of gases in soil respiration. SCI Monograph 37:152-171.

Environment Canada, 2004. Particles at work. Envirozine, Issue 49, Feature 3.

http://www.ec.gc.ca/EnviroZine/english/issues/49/feature3_e.cfm Verified Dec 2009. 
Global Carbon Project, 2009. Global Carbon Budget for 2008.

http://www.globalcarbonproject.org/carbonbudget/08/presentation.htm Verified Dec2009.

Hillel, D., 1998. Environmental Soil Physics. Academic Press, San Diego, CA.

Keele, C.A., Neil, E. and Joels, N., 1982. Samson Wright's applied physiology. $13^{\text {th }}$ ed., p.214. Oxford, Oxford Univ. Press.

Ludwig, W. and Probst, J.L., 1998, River sediment discharge to the oceans: present-day controls and global budget. American Journal of Science, 298, 265-295.

Murray, H.H. 1993. 'Clays in industry and the environment'. In Clays controlling the environment. Proceedings 10th International Clay Conference, Adelaide. CSIRO

Publishing, Melbourne, Australia.

Oliver, M.A. 1997. Soil and human health: a review. European J. Soil Sci. 48: 573-592.

Pimentel, D., 2006. Soil erosion: A food and environmental threat. Environment, Development and Sustainability 8: 119-137.

Pimentel, D., Harvey, C., Resosudarmo, P., Sinclair, K., Kurz, D., McNair, M., Crist, S., Shpritz, L., Fitton, R., Saffouri, R. and Blair, R. 1995. Environmental and economic costs of soil erosion and conservation benefits. Science 267: 1117-1123.

Shorter Oxford English Dictionary, 1970. Oxford University Press, London.

Snoeyink, V.L. and Jenkins, D. 1980. Water Chemistry. J.Wiley, N.Y.

Szabolcs, I., 1989. Salt-affected soils. CRC Press, Boca Raton, Fla.

Velde B., 1995. Origin and Mineralogy of Clays. Clays and the Environment. Springer, NY.

Vergano, D. 1996. Brave New World of Biosphere 2? Science News 150: 312-313.

Walker, A.F. 1990. Human Nutrition. (Table 1.1). Cambridge University Press, U.K.

Wilding, L.P. and Lin, H. 2005. Advancing the frontiers of soil science towards a geoscience. Geoderma 131: 257-274.

Wilkinson, B.H. and McElroy, B.J., 2007. The impact of humans on continental erosion and sedimentation. Geol. Soc. Am. Bull. 119: 140-156.

Yeates, G. 1989. Earthworms and agroforestry. Agrisearch, DSIR (NZ).

Yong, R.N., Mohamed, A. and Warkentin, B.P., 1992. Principles of contaminant transport in soils. Elsevier, Amsterdam. 